Arch. Tierz., Dummerstorf 47 (2004) 2, 165-171

Department of Genetics and Animal Breeding, Agricultural University of Poznan, Poland

MARIUSZ MACKOWSKI, MAREK SWITONSKI, JOANNA MACKOWSKA

and WOJCIECH PERZ

\title{
Polymorphism of the GPX-5 gene and characteristics of boar semen
}

\begin{abstract}
Two polymorphisms at intron 1 of the glutathione peroxidase 5 (GPX-5) gene, namely $A>G$ substitution (1B and 2B alleles) and deletion/insertion (1C and 2C alleles), were studied in a group of 140 AI boars. Alleles 2B and $1 \mathrm{C}$ were the most frequent ones -0.72 and 0.93 , respectively. Only two genotypes for each polymorphic site could be analysed with regard to three characteristics of semen: volume, sperm concentration and total sperm number in the ejaculate. Altogether, data on 13172 ejaculates were used in this study. It was found that 1B2B genotype was related to higher sperm concentration, while other traits demonstrated variable relationships with the genotypes, depending on the analysed breed. It may suggest that the GPX-5 gene is linked to an unknown QTL controlling sperm production.
\end{abstract}

Key Words: pig, GPX-5, ejaculate, boar

\section{Zusammenfassung}

Titel der Arbeit: Der GPX Gen Polymorphismus und Merkmale des Eberspermas

140 KB-Eber verschiedener Rassen wurden für zwei Polymorphismen A>G Substitution (Allels 1B und 2B) und Deletion/Insertion (Allels 1C und 2C) in Intron 1 des Glutathion Peroxidase 5 (GPX-5) Gens untersucht. Die Allele 2B und $1 \mathrm{C}$ waren am häufigsten mit Frequenzen von 0.72 beziehungsweise 0.93 . Zwei Genotypen wurden in Bezug auf drei Spermamerkmale analysiert, das waren Volumen, Spermakonzentration und gesamte Anzahl Spermien im Ejakulat. Ingesamt wurden Daten von 13172 Ejakulaten verwendet. Es konnte gezeigt werden, dass der 1B2B Genotyp mit einer höheren Spermakonzentration assoziiert war, während je nach Rasse andere Merkmale unterschiedliche Beziehungen mit den Genotypen aufwiesen. Die Ergebnisse dieser Studie lassen vermuten, dass das GPX-5 Gen mit einem unbekannten QTL für Spermaproduktion gekoppelt ist.

Schlüsselwörter: Schwein, GPX-5, Ejakulat, Eber

\section{Introduction}

The family of glutathione peroxidase (GPX) enzymes is involved in the deactivation of oxidative factors. The GPX-5 gene is expressed specifically in the epididymis (SCHWAAB et al., 1998) and the encoded protein binds to a cell membrane covering the acrosome of a sperm. It is anticipated that it inhibits premature acrosome reaction (HALL et al., 1998). Thus, polymorphism of this gene may have a major effect on reproductive performance.

It is known that the GPX-5 gene is localized within the swine major histocompability complex (SLA) which is assigned to chromosome 7 (BERTANI et al., 1999). The structure of the porcine GPX-5 gene is only partly described, but two polymorphic sites have been identified so far: (a) substitution $A \rightarrow G$, recognized by b the HinfI restriction enzyme and (b) deletion/insertion of 522 bp (BERTANI et al. 1999).

The aim of the present study was to evaluate the effects of two polymorphisms of the GPX-5 gene on the characteristics of semen produced by AI boars. 
Material and methods

Studies were performed on 140 boars (Polish Landrace - 45, Polish Large White - 27, Pietrain - 12, Hampshire - 4, Duroc - 2, Duroc x Pietrain - 24, Hampshire x Pietrain 21, Duroc x Belgian Landrace - 3, Duroc x Hampshire - 2) from an AI station in Poznan. Detailed information on 13172 ejaculates (volume - ml, and sperm concentration - the number of sperms in $1 \mathrm{ml}$ of ejaculate) was used in this study.

Two polymorphic sites in the GPX-5 gene were analysed, following the publication by BERTANI et al. (1999) (GenBank \#AF124818):

a) deletion/ insertion. Two fragments: 630bp and 110bp were amplified with the use of the following primers: forward 5'-TAG ACA CGT CAC TTC ACC TCC-3' and reverse 5’-GGG AGT AAG CAT TTT CTC TGT G-3’.

b) substitution $A \rightarrow G$. One 530bp fragment was amplified with the use of the following primers: forward 5'-TTC ATG TAG AAC TTA TTT CTG-3' and reverse 5'-TGA CTT ACC CAT TCT TCA G-3'. The amplified fragment was digested with the HinfI restriction enzyme (Fermentas).

To evaluate the effect of the two polymorphisms on semen characteristics the following linear model was applied:

$y_{i j k l m}=\mu+r_{i}+g_{j}+a_{i j k}+s_{l}+(r g)_{i j}+b t_{i j k l m}+e_{i j k l m}$

where:

$y_{i j k l m}$ - the characteristic under consideration of $m$-th ejaculate of $k$-th boar,

$\mu$ - mean,

$r_{i}$ - effect of the $i$-th breed,

$g_{j}$ - effect of the $j$-th genotype at GPX-5,

$a_{i j k}-$ effect of the $k$-th boar (of breed $i$ and genotype $j$ ),

$s_{l}$ - effect of the $l$-th season,

$b$ - regression coefficient,

$t_{i j k l m}$ - covariate for age at ejaculation (measured in days),

$e_{i j k l m}$ - error.

The F-test was applied to estimate significance of the effects included in the model.

Particular differences of means within groups were analyzed with the Fisher test of least significant differences (LSD).

\section{Results}

An analysis of homology between the porcine fragment of the GPX-5, described by BERTANI et al. (1999, GenBank \#AF124818) and the human sequence (GenBank \#NM 003996) revealed that the two detected polymorphic sites are present in intron 1 of this gene. Genotypes at two polymorphic sites: (a) substitution $A \rightarrow G$ - alleles $1 B$ and 2B, and (b) deletion/insertion - alleles 1C and 2C were established for all the 140 boars (Figs. 1 and 2). The frequencies of the genotypes and genes are shown in Table 1. At the first polymorphic site the frequency of allele $2 \mathrm{~B}$ was predominant in all the studied groups of boars and the average frequency reached 0.72. At the second polymorphic site monomorphism (1C1C) occurred in two breeds (Polish Large White and Pietrain) and two crossbred groups (Duroc x Belgian Landrace and Hampshire $\mathrm{x}$ Pietrain). In the other breeds the 1C1C genotype also appeared to be the most frequent. Thus, overall frequency of $1 \mathrm{C}$ allele was very high (0.93). 


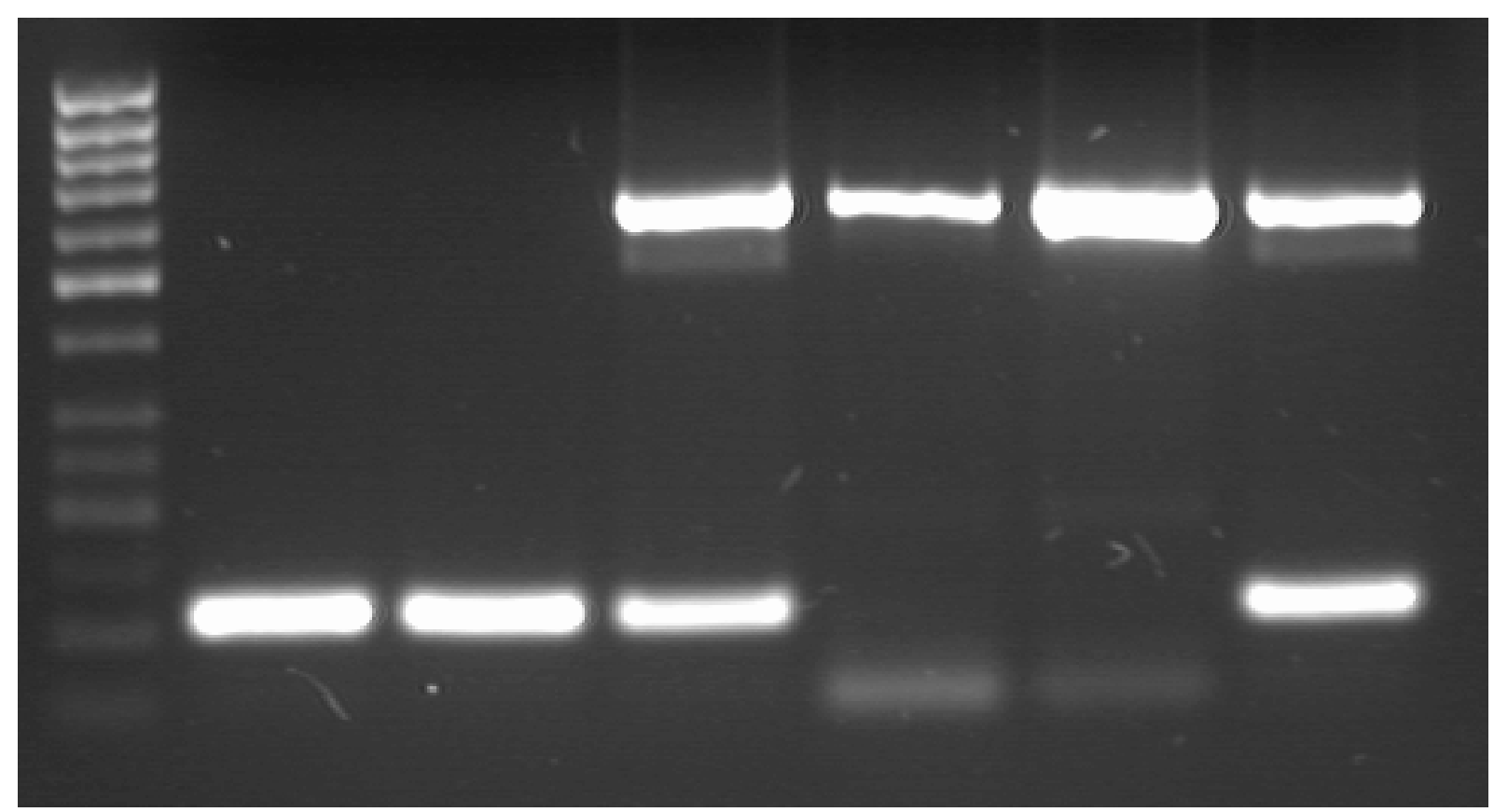

Fig. 1.: Deletion/Insertion detection in the GPX-5: 1- GeneRuler ${ }^{\mathrm{TM}}$ 50bp DNA Ladder (Fermentas), 2 and 3 2C/2C, 4 and 7 - 1C/2C, 5 and 6 - 1C/1C (Deletion/Insertion-Analyse des GPX-5: 1 - GeneRuler ${ }^{\mathrm{TM}}$ 50bp DNA Ladder (Fermentas), 2 und 3 - 2C/2C, 4 und 7 - 1C/2C, 5 und 6 - 1C/1C)

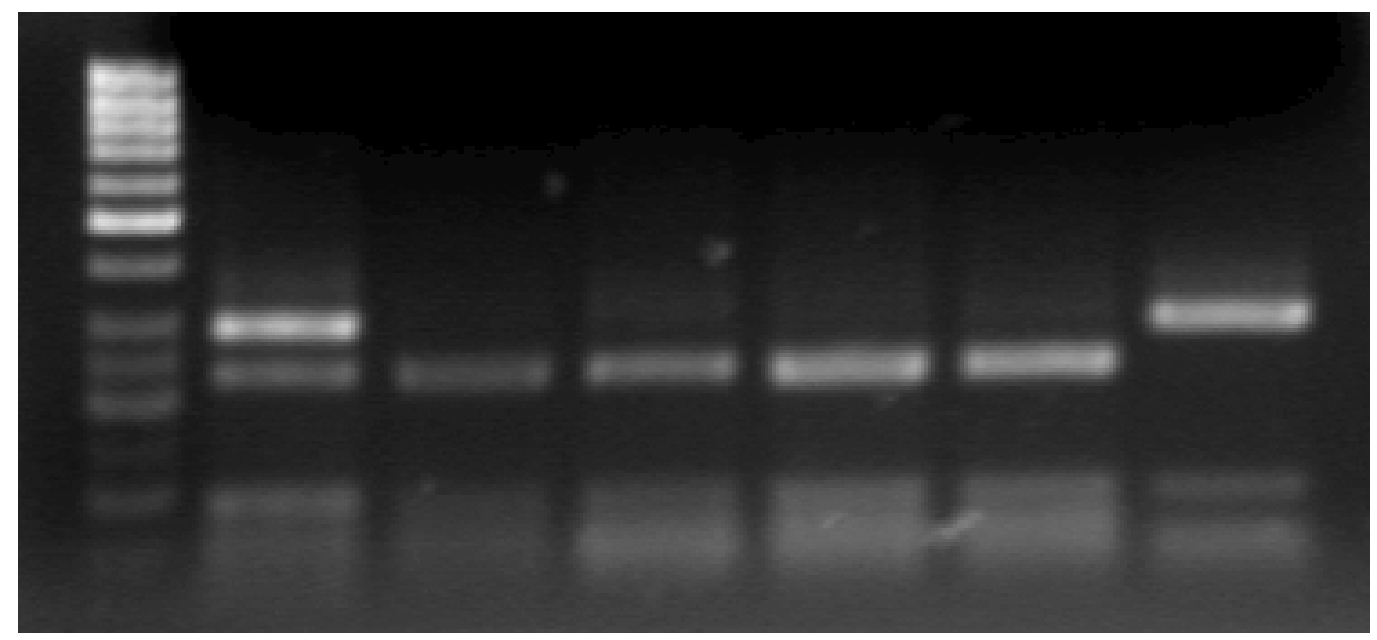

Fig. 2: RFLP/HinfI analysis of the GPX-5: 1 - GeneRuler ${ }^{\mathrm{TM}}$ 50bp DNA Ladder (Fermentas), 2 - 1B/2B, 3-6 2B/2B, 7 - 1B/1B (Restriction-Analyse (HinfI) des GPX-5: 1 - GeneRuler ${ }^{\mathrm{TM}}$ 50bp DNA Ladder (Fermentas), 2 1B/2B, 3-6 - 2B/2B, 7 - 1B/1B)

Low frequencies of two homozygous genotypes (1B1B and 2C2C) made it impossible to compare all the three genotypes at both sites in relation to characteristics of ejaculates. Therefore, only two genotypes for both sites were considered. Moreover, in the analysis only breeds or crossbred groups with a sufficient number of animals (at least five), representing both genotypes, were taken into consideration. In case of the Hinfl polymorphism a quite clear relationship between the genotype and the analyzed traits was observed. The mean volume of ejaculates in case of the 2B2B genotype (298 $\mathrm{ml}$ ) was significantly higher than for the 1B2B one $(280 \mathrm{ml})$; however, this was not observed in case of the Duroc x Pietrain boars. With regard to the second trait - sperm concentration - the mean value was higher for the 1B2B genotype $\left(445 \times 10^{6}\right)$ than for 
the 2B2B genotype $\left(411 \times 10^{6}\right)$. This relationship was observed in all the studied groups of boars, with the exception of the Duroc $x$ Pietrain crossbreds. Since the observed relationships were contradictory (a higher volume but lower sperm concentration for the 2B2B genotype, and vice versa for the $2 \mathrm{~B} 1 \mathrm{~B}$ one), the mean number of sperms in the ejaculate was estimated (volume $\mathrm{x}$ sperm concentration). This characteristic appeared to be higher for the 1B2B boars $\left(119 \times 10^{9}\right)$. However, this relation was not persistent in all the analyzed groups. In the Polish Large White and Duroc $x$ Pietrain this genotype was superior, but it was not in case of the Polish Landrace and Hampshire $\mathrm{x}$ Pietrain crossbreds.

Table 1

Genotype and allele frequencies at the GPX-5 locus (Genotypen und Allelfrequenzen am GPX-5 Locus)

\begin{tabular}{|c|c|c|c|c|c|c|c|c|c|c|c|}
\hline \multirow[t]{3}{*}{ Breed } & \multirow{3}{*}{$\begin{array}{l}\text { Number } \\
\text { of boars }\end{array}$} & \multicolumn{5}{|c|}{ HinfI polymorphism } & \multicolumn{5}{|c|}{ Deletion/insertion polymorphism } \\
\hline & & \multicolumn{3}{|c|}{ Genotypes } & \multicolumn{2}{|c|}{ Alleles } & \multicolumn{3}{|c|}{ Genotypes } & \multicolumn{2}{|c|}{ Alleles } \\
\hline & & 1B1B & 1B2B & 2B2B & $1 \mathrm{~B}$ & $2 \mathrm{~B}$ & $1 \mathrm{C} 1 \mathrm{C}$ & $1 \mathrm{C} 2 \mathrm{C}$ & $2 \mathrm{C} 2 \mathrm{C}$ & $1 \mathrm{C}$ & $2 \mathrm{C}$ \\
\hline $\begin{array}{l}\text { Polish } \\
\text { Landrace }\end{array}$ & 45 & 0.00 & 0.46 & 0.54 & 0.23 & 0.77 & 0.87 & 0.13 & 0.00 & 0.94 & 0.06 \\
\hline $\begin{array}{l}\text { Polish } \\
\text { Large } \\
\text { White }\end{array}$ & 27 & 0.00 & 0.70 & 0.30 & 0.35 & 0.65 & 1.00 & 0.00 & 0.00 & 1.00 & 0.00 \\
\hline $\begin{array}{l}\text { Duroc x } \\
\text { Pietrain }\end{array}$ & 24 & 0.08 & 0.34 & 0.58 & 0.38 & 0.62 & 0.79 & 0.21 & 0.00 & 0.90 & 0.10 \\
\hline $\begin{array}{l}\text { Hampshire } \\
\text { x Pietrain }\end{array}$ & 21 & 0.00 & 0.48 & 0.52 & 0.24 & 0.76 & 1.00 & 0.00 & 0.00 & 1.00 & 0.00 \\
\hline Pietrain & 12 & 0.00 & 0.16 & 0.84 & 0.08 & 0.92 & 1.00 & 0.00 & 0.00 & 1.00 & 0.00 \\
\hline Hampshire & 4 & 0.50 & 0.25 & 0.25 & 0.63 & 0.37 & 0.25 & 0.50 & 0.25 & 0.63 & 0.37 \\
\hline Duroc & 2 & 0.00 & 1.00 & 0.00 & 0.50 & 0.50 & 0.50 & 0.50 & 0.00 & 0.75 & 0.25 \\
\hline $\begin{array}{l}\text { Duroc x } \\
\text { Belgian } \\
\text { Landrace } \\
\end{array}$ & 3 & 0.00 & 0.00 & 1.00 & 0.00 & 1.00 & 1.00 & 0.00 & 0.00 & 1.00 & 0.00 \\
\hline $\begin{array}{l}\text { Duroc x } \\
\text { Hampshire }\end{array}$ & 2 & 0.00 & 0.50 & 0.50 & 0.25 & 0.75 & 0.50 & 0.50 & 0.00 & 0.75 & 0.25 \\
\hline TOTAL & 140 & 0.03 & 0,46 & 0.51 & 0.28 & 0.72 & 0.88 & 0.11 & 0.01 & 0.93 & 0.07 \\
\hline
\end{tabular}

Table 2

HinfI polymorphism of the GPX-5 gene in relation to characteristics of ejaculates (HinfI Polymorphismus des GPX-5 Gens in Bezug auf die Spermamerkmale)

\begin{tabular}{|c|c|c|c|c|c|c|c|c|}
\hline \multirow[b]{2}{*}{ Breed } & \multicolumn{4}{|c|}{ 1B2B genotype } & \multicolumn{4}{|c|}{ 2B2B genotype } \\
\hline & $\begin{array}{l}\text { Number of } \\
\text { boars } \\
\text { (number of } \\
\text { ejaculates) }\end{array}$ & $\begin{array}{c}\text { Mean } \\
\text { volume } \\
\text { (standard } \\
\text { deviation) } \\
\text { ml }\end{array}$ & $\begin{array}{c}\text { Mean } \\
\text { concen- } \\
\text { tration } \\
\text { (standard } \\
\text { deviation) } \\
\times 10^{6}\end{array}$ & $\begin{array}{c}\text { Mean } \\
\text { number } \\
\text { of sperms } \\
\text { x } 10^{9}\end{array}$ & $\begin{array}{c}\text { Number } \\
\text { of boars } \\
\text { (number } \\
\text { of ejacu- } \\
\text { lates) }\end{array}$ & $\begin{array}{c}\text { Mean } \\
\text { volume } \\
\text { (standard } \\
\text { deviation) } \\
\text { ml }\end{array}$ & $\begin{array}{c}\text { Mean } \\
\text { concen- } \\
\text { tration } \\
\text { (standard } \\
\text { deviation) } \\
\text { x } 10^{6}\end{array}$ & $\begin{array}{c}\text { Mean } \\
\text { number } \\
\text { of sperms } \\
\text { x } 10^{9}\end{array}$ \\
\hline $\begin{array}{l}\text { Polish } \\
\text { Landrace }\end{array}$ & $\begin{array}{c}21 \\
(2108)\end{array}$ & $\begin{array}{c}253 * * \\
(78)\end{array}$ & $\begin{array}{c}437 * * \\
(111)\end{array}$ & $\begin{array}{c}107 * * \\
(33)\end{array}$ & $\begin{array}{c}24 \\
(2600)\end{array}$ & $\begin{array}{c}295 * * \\
(105)\end{array}$ & $\begin{array}{c}406 * * \\
(115)\end{array}$ & $\begin{array}{c}113^{* *} \\
(32)\end{array}$ \\
\hline $\begin{array}{l}\text { Polish } \\
\text { Large } \\
\text { White }\end{array}$ & $\begin{array}{c}18 \\
(1037)\end{array}$ & $\begin{array}{c}294 * * \\
(103)\end{array}$ & $\begin{array}{c}493 * * \\
(119)\end{array}$ & $\begin{array}{c}137 * * \\
(36)\end{array}$ & $\begin{array}{c}8 \\
(601)\end{array}$ & $\begin{array}{c}375 * * \\
(191)\end{array}$ & $\begin{array}{c}368 * * \\
(156)\end{array}$ & $\begin{array}{c}117 * * \\
(36)\end{array}$ \\
\hline $\begin{array}{l}\text { Duroc } \mathrm{x} \\
\text { Pietrain }\end{array}$ & $\begin{array}{c}8 \\
(683)\end{array}$ & $\begin{array}{c}293 * * \\
(80)\end{array}$ & $\begin{array}{l}448 \\
(91)\end{array}$ & $\begin{array}{c}128 * * \\
(35)\end{array}$ & $\begin{array}{c}16 \\
(1350)\end{array}$ & $\begin{array}{c}243 * * \\
(65)\end{array}$ & $\begin{array}{c}455 \\
(114)\end{array}$ & $\begin{array}{c}107 * * \\
(30)\end{array}$ \\
\hline $\begin{array}{l}\text { Hampshire } \\
\text { x Pietrain }\end{array}$ & $\begin{array}{c}10 \\
(1008)\end{array}$ & $\begin{array}{l}307 * * \\
(119)\end{array}$ & $\begin{array}{l}410 * * \\
(110)\end{array}$ & $\begin{array}{c}118^{* *} \\
(33)\end{array}$ & $\begin{array}{c}11 \\
(861)\end{array}$ & $\begin{array}{c}337 * * \\
(99)\end{array}$ & $\begin{array}{c}385 * * \\
(98)\end{array}$ & $\begin{array}{c}126 * * \\
(37)\end{array}$ \\
\hline TOTAL & $\begin{array}{c}57 \\
(4836)\end{array}$ & $\begin{array}{c}280 * * \\
(97)\end{array}$ & $\begin{array}{c}445^{* *} \\
(113)\end{array}$ & $\begin{array}{c}119 * * \\
(36)\end{array}$ & $\begin{array}{c}59 \\
(5412)\end{array}$ & $\begin{array}{c}298 * * \\
(117)\end{array}$ & $\begin{array}{l}411^{* *} \\
(121)\end{array}$ & $\begin{array}{c}114^{* *} \\
(34)\end{array}$ \\
\hline
\end{tabular}


The effect of the deletion/insertion polymorphism was studied, due to an insufficient number of boars with the 1C2C genotype, only in two groups of boars: Polish Landrace and Duroc x Pietrain crossbreds (Table 3). It was found that the mean volume of the ejaculate was higher for the 1C2C genotype $\left(280 \times 10^{9}\right)$. This relationship was observed in both analyzed groups. On the other hand, the variability of the mean sperm concentration was not concordant in both groups - higher for boars with the 1C1C genotype of the Polish Landrace, but lower in case of the Duroc $\mathrm{x}$ Pietrain crossbreds. The mean number of sperms in the ejaculate was slightly higher for boars with the 1C2C genotype.

Table 3

Deletion/insertion polymorphism of the GPX-5 gene in relation to characteristics of ejaculates (Deletion/ Insertion Polymorphismus des GPX-5 Gens in Bezug auf die Merkmale des Samen)

\begin{tabular}{|c|c|c|c|c|c|c|c|c|}
\hline \multirow[b]{2}{*}{ Breed } & \multicolumn{4}{|c|}{ 1C1C genotype } & \multicolumn{4}{|c|}{ 1C2C genotype } \\
\hline & $\begin{array}{c}\text { Number } \\
\text { of boars } \\
\text { (number } \\
\text { of } \\
\text { ejaculates) }\end{array}$ & $\begin{array}{c}\text { Mean } \\
\text { volume } \\
\text { (standard } \\
\text { deviation) } \\
\text { ml }\end{array}$ & $\begin{array}{c}\text { Mean } \\
\text { concen- } \\
\text { tration } \\
\text { (standard } \\
\text { deviation) } \\
\quad \times 10^{6}\end{array}$ & $\begin{array}{c}\text { Mean } \\
\text { number of } \\
\text { sperms }\end{array}$ & $\begin{array}{c}\text { Number } \\
\text { of boars } \\
\text { (number } \\
\text { of } \\
\text { ejaculates) }\end{array}$ & $\begin{array}{c}\text { Mean } \\
\text { volume } \\
\text { (standard } \\
\text { deviation) } \\
\text { ml }\end{array}$ & $\begin{array}{c}\text { Mean } \\
\text { concen- } \\
\text { tration } \\
\text { (standard } \\
\text { deviation) } \\
\quad \times 10^{6}\end{array}$ & $\begin{array}{c}\text { Mean } \\
\text { number of } \\
\text { sperms }\end{array}$ \\
\hline $\begin{array}{l}\text { Polish } \\
\text { Landrace }\end{array}$ & $\begin{array}{c}39 \\
(4064) \\
\end{array}$ & $\begin{array}{c}276^{*} \\
(98) \\
\end{array}$ & $\begin{array}{c}423 * * \\
(113) \\
\end{array}$ & $\begin{array}{l}110 \\
(32) \\
\end{array}$ & $\begin{array}{c}6 \\
(643)\end{array}$ & $\begin{array}{c}285^{*} \\
(86) \\
\end{array}$ & $\begin{array}{c}401^{* *} \\
(119) \\
\end{array}$ & $\begin{array}{l}111 \\
(38)\end{array}$ \\
\hline $\begin{array}{l}\text { Duroc x } \\
\text { Pietrain } \\
\end{array}$ & $\begin{array}{c}19 \\
(1675) \\
\end{array}$ & $\begin{array}{c}254 * * \\
(74) \\
\end{array}$ & $\begin{array}{c}453 * * \\
(111) \\
\end{array}$ & $\begin{array}{c}112 * * \\
(32) \\
\end{array}$ & $\begin{array}{c}5 \\
(425) \\
\end{array}$ & $\begin{array}{c}271 * * \\
(74)\end{array}$ & $\begin{array}{c}476^{* *} \\
(117)\end{array}$ & $\begin{array}{c}125 * * \\
(34) \\
\end{array}$ \\
\hline TOTAL & $\begin{array}{c}58 \\
(5739)\end{array}$ & $\begin{array}{c}269 * * \\
(92)\end{array}$ & $\begin{array}{c}432 \\
(113)\end{array}$ & $\begin{array}{l}111 \\
(32)\end{array}$ & $\begin{array}{c}11 \\
(1068)\end{array}$ & $\begin{array}{c}280 * * \\
(82)\end{array}$ & $\begin{array}{c}431 \\
(117)\end{array}$ & $\begin{array}{l}117 \\
(37)\end{array}$ \\
\hline
\end{tabular}

* $\mathrm{P}<0.05 ; * * \mathrm{P}<0.01$

Table 4

Effect of intragenic haplotype on characteristics of ejaculates (Intragenetik Haplotyp Effekt in Bezug auf die Spermamerkmale)

\begin{tabular}{|c|c|c|c|c|c|c|c|c|}
\hline Breed & $\begin{array}{l}\text { Number of } \\
\text { boars } \\
\text { (number of } \\
\text { ejaculates) }\end{array}$ & $\begin{array}{c}\text { Mean } \\
\text { volume } \\
\text { (standard } \\
\text { deviation) } \\
\text { ml }\end{array}$ & $\begin{array}{c}\text { Mean } \\
\text { concen- } \\
\text { tration } \\
\text { (standard } \\
\text { deviation) } \\
\quad \times 10^{6}\end{array}$ & $\begin{array}{c}\text { Mean } \\
\text { number of } \\
\text { sperms } \\
\text { (standard } \\
\text { deviation) } \\
\text { x } 10^{9}\end{array}$ & $\begin{array}{l}\text { Number of } \\
\text { boars } \\
\text { (number of } \\
\text { ejaculates) }\end{array}$ & $\begin{array}{c}\text { Mean } \\
\text { volume } \\
\text { (standard } \\
\text { deviation) } \\
\text { ml }\end{array}$ & $\begin{array}{c}\text { Mean } \\
\text { concen- } \\
\text { tration } \\
\text { (standard } \\
\text { deviation) } \\
\quad \times 10^{6}\end{array}$ & $\begin{array}{c}\text { Mean } \\
\text { number of } \\
\text { sperms } \\
\text { (standard } \\
\text { deviation) } \\
\text { x } 10^{9}\end{array}$ \\
\hline Haplotype & \multicolumn{4}{|c|}{$1 C 1 C-1 B 2 B$} & \multicolumn{4}{|c|}{$1 C 1 C-2 B 2 B$} \\
\hline $\begin{array}{c}\text { Polish } \\
\text { Landrace }\end{array}$ & $14(1454)$ & $220 *(59)$ & $460(56)$ & $98(23)$ & $24(2600)$ & $270 *(67)$ & $442(72)$ & 112 (21) \\
\hline $\begin{array}{l}\text { Polish Large } \\
\text { White }\end{array}$ & 18 (1037) & $266(74)$ & $497 *(87)$ & $128(21)$ & $8(601)$ & 338 (139) & $392 *(107)$ & $120(30)$ \\
\hline $\begin{array}{l}\text { Duroc } x \\
\text { Pietrain }\end{array}$ & 5 (327) & 272 (49) & $462(46)$ & $122(16)$ & $14(1260)$ & 225 (42) & $478(64)$ & 104 (18) \\
\hline $\begin{array}{c}\text { Hampshire } \mathrm{x} \\
\text { Pietrain }\end{array}$ & $10(1008)$ & 291 (99) & 409 (78) & 111 (23) & 11 (861) & 296 (71) & $416(56)$ & 119 (25) \\
\hline TOTAL & 47 (3826) & $258(77)$ & $463(78)$ & 115 (25) & 57 (5322) & 274 (83) & 439 (77) & $113(23)$ \\
\hline Haplotype & \multicolumn{4}{|c|}{$1 B 2 B-1 C 1 C$} & \multicolumn{4}{|c|}{$1 B 2 B-1 C 2 C$} \\
\hline $\begin{array}{c}\text { Polish } \\
\text { Landrace }\end{array}$ & 15 (1464) & $217 *(58)$ & 466 (60) & $98(23)$ & $6(644)$ & $264 *(60)$ & $458(60)$ & $116(18)$ \\
\hline
\end{tabular}


In addition, the effect of the intragene haplotype was also evaluated. Due to low numbers of boars only two comparisons were performed: (a) 1C1C-1B2B versus 1C1C-2B2B, and (b) 1C1C-1B2B versus 1C2C-1B2B (Table 4). The first comparison facilitated the estimation of the effect of two genotypes 1B2B and 2B2B, since at the other site the same genotype was present - 1C2C. It was found that 1C1C-2B2B was related with a slightly higher mean volume of the ejaculate, with the exception of the Duroc $x$ Pietrain crossbreds, and sperm concentration was higher for the 1B2B genotype, but the mean number of sperms was rather similar for both groups. These results confirmed the observations when a single polymorphic site (1B2B) was considered (Table 2). The second comparison was performed to estimate the effect of the $1 \mathrm{C} 1 \mathrm{C}$ and $1 \mathrm{C} 2 \mathrm{C}$ genotypes, accompanied by the 1B2B genotype. In this comparison only one group (Polish Landrace) could be included. The results obtained for the 1B2B-1C2C boars (a higher mean volume, a lower sperm concentration and a higher number of sperms in the ejaculate) confirmed the observed differences of the effect of a single polymorphic site (Table 3).

\section{Discussion}

The importance of the GPX5 gene polymorphism in the context of boar fertility, due to a possible role which is played by this gene in the sperm-egg interaction, was suggested by BERTANI et al. (1999). The authors pointed out that allele 2C was predominant $(\mathrm{q}=0.57)$ in the Hampshire breed in which boars with low fertility are identified quite frequently. In spite of a very low frequency of this allele we also found it in the genotypes of three Hampshire boars (one with genotype 2C2C and two heterozygotes - 1C2C) out of the four studied animals, but none of the twenty one Hampshire x Pietrain crossbred boars carried it. BERTANI et al. (1999) also reported a quite frequent ( $\mathrm{q}=0.29$ ) occurrence of this allele in the Landrace breed. In our study this frequency was much lower $(\mathrm{q}=0.06)$. With regard to the $\mathrm{B}$ site the observed distribution of two alleles $(1 \mathrm{~B}-0.24$ and $2 \mathrm{~B}-0.76$ ) was similar to those described by KMIEĆ et al. (2002) who analysed a group of Hampshire x Pietrain crossbred boars. Until now there are very few data on the identification of chromosome regions carrying potential QTLs for sperm production. It was only reported that a gene (or genes) regulating testicular development and pubertal gonadotropin - FSH and LH concentrations may reside on chromosome X (FORD et al., 2001). The authors performed investigations on Chinese Meishan $\mathrm{x}$ White composite crossbred boars and showed that the boars that inherited X-linked alleles from the Meishan breed had smaller testes and a reduced daily sperm production. In an earlier study of this team, it was also suggested that a QTL affecting the concentration of serum FSH may also occur on other chromosomes, including chromosome 7 (ROHRER et al., 2000). Unfortunately, its detailed localization in relation to the GPX5 gene, which is also localized on this chromosome, is not known.

A lack of a strong relationship between the GPX5 gene polymorphism and sperm production is not surprising since the anticipated effect of the encoded protein concerns rather the fertilizability of sperms, rather than the production efficiency of testes. On the other hand, the observed significant effect of the 1B2B genotype on a higher sperm concentration suggests that the $1 \mathrm{~B}$ allele is superior for semen production. This is in agreement with the data published by KMIEC et al. (2002) who compared all the three possible genotypes in a group of 34 Hampshire $x$ Pietrain boars 
and observed a significantly higher concentration for the 1B2B genotype than for the two other homozygotes. These results may suggest that the GPX5 gene can be considered as a marker which is linked with an unknown QTL controlling the production of semen and due to the linkage phase variable effects of the GPX5 genotypes are observed.

\section{References}

BERTANI, G.R.; MARLUND, S.; HU, Z.L.; ROTHSCHILD, M.F.:

Mapping of the Gltauthione-peroxidase-5 (GPX5) gene to pig chromosome 7. J. Anim. Sci., 77 (1999), 2855-2856

FORD, J.J.; WISE, T.H.; LUNSTRA, D.D.; ROHRER, G.A.:

Interrelationships of porcine $\mathrm{X}$ and $\mathrm{Y}$ chromosomes with pituitary gonadotropins and testicular size. Biol. Reprod., 65 (2001), 906-912

HALL, L., WILLIAMS, K., PERRY A.C.F., FRAYNE J., JURY J.A.:

The majority of human glutathione peroxidase type 5 (GPX5) transcripts are incorrectly spliced: implications for the role of GPX5 in the male reproductive tract. Biochem. J., 333 (1998), 5-8

KMIEĆ, M.; DYBUS, A.; KONIK, A.:

Polymorphism of Glutathione Peroxidase 5 (GPX5) gene and its effect on some semen characters in boars. Ann. Anim. Sci., 2 (2002) (Suppl.), 123-126

ROHRER, G.A.; FORD, J.J.; WISE, T.:

A preliminary genomic scan for chromosomal regions affecting plasma FSH concentrations in pubertal boars. J. Anim. Sci., 78 (2000) (Suppl. 2), 27

SCHWAAB, V.; LAREYRE, J.J.; VERNET, P.; PONS, E.; FAURE, J.; DUFAURE, J.P.; DREVET, J.R.:

Characterization, regulation of the expression and putative roles of two glutathione peroxidase proteins found in the mouse epididymis. J. Reprod. Fertil. 53 (1998) (Suppl.), 157-162

Received: 2003-09-18

Accepted: 2004-02-27

Author's address

MARIUSZ MACKOWSKI MSc., Prof. MAREK SWITONSKI, PhD (corresponding author), JOANNA MACKOWSKA MSc., WOJCIECH PERZ, PhD.

Department of Genetics and Animal Breeding

August Cieszkowski Agricultural University of Poznan

Wołyńska 33,

60-637 Poznan

Poland

E-Mail: switonsk@jay.au.poznan.pl 